Article

\title{
Low-Temperature, Chemically Grown Titanium Oxide Thin Films with a High Hole Tunneling Rate for Si Solar Cells
}

\author{
Yu-Tsu Lee ${ }^{1}$, Fang-Ru Lin ${ }^{1}$, Ting-Chun Lin ${ }^{1}$, Chien-Hsun Chen ${ }^{4}$ and Zingway Pei ${ }^{1,2,3, *}$ \\ 1 Department of Electrical Engineering, National Chung Hsing University, Taichung 40227, Taiwan; \\ bill90867@hotmail.com (Y.-T.L.); ginkgo0518@hotmail.com (F.-R.L.); lin46094@gmail.com (T.-C.L.) \\ 2 Graduate Institute of Optoelectronic Engineering, National Chung Hsing University, Taichung 40227, Taiwan \\ 3 Research Center for Sustainable Energy and Nanotechnology, National Chung Hsing University, \\ Taichung 40227, Taiwan \\ 4 Green Energy and Environment Research Laboratories, Industrial Technology Research Institute, \\ Chutung 310, Taiwan; tantalus@itri.org.tw \\ * Correspondence: zingway@dragon.nchu.edu.tw; Tel.: +886-4-2285-1549 (ext. 801) \\ Academic Editor: Alessio Bosio \\ Received: 8 March 2016; Accepted: 19 May 2016; Published: 25 May 2016
}

\begin{abstract}
In this paper, we propose a chemically grown titanium oxide $\left(\mathrm{TiO}_{2}\right)$ on $\mathrm{Si}$ to form a heterojunction for photovoltaic devices. The chemically grown $\mathrm{TiO}_{2}$ does not block hole transport. Ultraviolet photoemission spectroscopy was used to study the band alignment. A substantial band offset at the $\mathrm{TiO}_{2} / \mathrm{Si}$ interface was observed. X-ray photoemission spectroscopy (XPS) revealed that the chemically grown $\mathrm{TiO}_{2}$ is oxygen-deficient and contains numerous gap states. A multiple-trap-assisted tunneling (TAT) model was used to explain the high hole injection rate. According to this model, the tunneling rate can be $10^{5}$ orders of magnitude higher for holes passing through $\mathrm{TiO}_{2}$ than for flow through $\mathrm{SiO}_{2}$. With 24-nm-thick $\mathrm{TiO}_{2}$, a Si solar cell achieves a $33.2 \mathrm{~mA} / \mathrm{cm}^{2}$ photocurrent on a planar substrate, with a $9.4 \%$ power conversion efficiency. Plan-view scanning electron microscopy images indicate that a moth-eye-like structure formed during $\mathrm{TiO}_{2}$ deposition. This structure enables light harvesting for a high photocurrent. The high photocurrent and ease of production of chemically grown $\mathrm{TiO}_{2}$ imply that it is a suitable candidate for future low-cost, high-efficiency solar cell applications.
\end{abstract}

Keywords: titanium oxide; chemically grown; heterojunction; band alignment; hole tunneling

\section{Introduction}

Heterojunction solar cells have recently become leading candidates for high-efficiency cells with a considerably low production cost. Heterojunctions are widely used in optoelectronic devices such as light-emitting diodes (LEDs) [1-4], laser diodes [5,6], and photodiodes (PDs) [7-9] because they enable manipulating either hole or electron transport selectively by applying an appropriate band alignment. The specific band alignment can either increase carrier recombination in a LED or move photocarriers into appropriate contact in a PD. A solar cell, an energy harvesting device, is a type of PD. To achieve a high photocurrent, holes and electrons should arrive at a specific electrode properly. Therefore, several material systems have been proposed and demonstrated to achieve appropriate heterojunctions in $\mathrm{Si}$ solar cells. Amorphous Si is a well-known material system deposited on crystalline Si to construct a heterojunction for high-efficiency solar cells by setting front and back surface fields [10]. A very thin (5-10 nm) intrinsic amorphous Si (a-Si:H) layer and a heavily p-type-doped amorphous Si (p-a-Si:H) layer were deposited sequentially through plasma-enhanced chemical vapor deposition (PECVD). The purpose of the intrinsic a-Si:H is to passivate the $\mathrm{Si}$ surface with hydrogen to prevent carrier 
recombination. However, this is a challenging process because PECVD involves ionic radicals that might damage the $\mathrm{Si}$ surface rather than passivate it. Although the a-Si:H-based heterojunction with intrinsic thin-film technology has demonstrated high efficiency, an alternative material that inherently exhibits excellent surface passivation and proper band alignment is required. Therefore, in addition to a-Si:H, metal oxides such as $\mathrm{AlO}_{x}[11-13], \mathrm{SiO}_{2}[14,15]$, and $\mathrm{TiO}_{2}[16,17]$ have been used in constructing carrier selective barriers with passivation ability on crystalline $\mathrm{Si}$ to achieve a high photocurrent. Pudasaini et al. [11] used ultrathin aluminum oxide (approximately $1.84 \mathrm{~nm}$ ), grown through an atomic layer deposition, on an n-type $\mathrm{Si}$ wafer as a passivation layer in a poly(3,4-ethylenedioxythiophene) polystyrene sulfonate/Si hybrid heterojunction solar cell system. Sheng et al. [14] used a wet method to form silicon oxide on a Si wafer as a passivation layer. A 10.48\% efficiency was achieved in a hybrid solar cell. Avasthi et al. [16] used low temperature chemical vapor deposition (CVD)-grown $\mathrm{TiO}_{2}(3 \mathrm{~nm})$ on a p-type wafer to block holes, thereby achieving a 7.02\% photoelectric conversion efficiency. Among the aforementioned materials, $\mathrm{TiO}_{2}$ is the most attractive because it exhibits a smaller bandgap that ensures efficient carrier tunneling. Furthermore, $\mathrm{TiO}_{2}$ was demonstrated to be an alternative to silicon nitride as a Si surface passivation layer [18]. However, CVD is a slow and expensive process that might limit productivity in the future. Moreover, $\mathrm{n}$-type $\mathrm{Si}$ is preferred to p-type $\mathrm{Si}$ in solar cells because electrons move faster than holes do. Therefore, chemically depositing $\mathrm{TiO}_{2}$ at a low temperature is proposed for attaining a high hole tunneling rate on an n-type Si substrate for heterojunction solar cells.

\section{Experimental}

An n-type, surface polished (100) Si wafer (1-10 $\Omega$-cm) $525 \mu \mathrm{m}$ in thickness was diced into tiles with areas of $2 \times 2 \mathrm{~cm}^{2}$ and used as the substrate. Prior to deposition, the Si substrate was cleaned chemically in a solution with an $\mathrm{HF}: \mathrm{H}_{2} \mathrm{O}$ ratio of $1: 10$ for $30 \mathrm{~s}$ and then rinsed in deionized water. After the substrate was cleaned, a layer of $\mathrm{TiO}_{2} 24-48 \mathrm{~nm}$ in thickness was deposited through liquid phase deposition (LPD). The deposition system consisted of:

(1) an environment that was temperature controlled at an accuracy of $\pm 0.1^{\circ} \mathrm{C}$;

(2) a Teflon vessel containing the deposition solution.

To form the deposition solution, $\left(\mathrm{NH}_{4}\right)_{2} \mathrm{TiF}_{6}$ and $\mathrm{H}_{3} \mathrm{BO}_{3}$ were dissolved in deionized water at concentrations of $0.2 \mathrm{M}$ and $0.6 \mathrm{M}$, respectively. To deposit $\mathrm{TiO}_{2}$, this solution was saturated with $\mathrm{TiO}_{2}$ powder. The deposition temperature was maintained at $40{ }^{\circ} \mathrm{C}$.

The mechanism for chemically growing $\mathrm{TiO}_{2}$ consists of two equilibrium reactions. The first is ligand exchange between metal-fluoro-complex ions (Equation (1)), and the second is an $\mathrm{F}^{-}$ion consuming reaction in which boric acid serves as an $\mathrm{F}^{-}$scavenger (Equation (2)) [19].

$$
\begin{gathered}
{\left[\mathrm{TiF}_{6}\right]^{2-}+n \mathrm{H}_{2} \mathrm{O} \leftrightarrow\left[\mathrm{TiF}_{6-n}(\mathrm{OH})_{n}\right]^{2-}+n \mathrm{HF}} \\
\mathrm{H}_{3} \mathrm{BO}_{3}+4 \mathrm{HF} \leftrightarrow \mathrm{HBF}_{4}+3 \mathrm{H}_{2} \mathrm{O}
\end{gathered}
$$

$\mathrm{H}_{3} \mathrm{BO}_{3}$ reacts readily with $\mathrm{F}^{-}$to form stable $\mathrm{BF}_{4}{ }^{-}$ions, thereby promoting the consumption of uncoordinated $\mathrm{F}$ ions. $\mathrm{TiO}_{2}$ dissolves in the solution and reacts with $\left(\mathrm{NH}_{4}\right)_{2} \mathrm{TiF}_{6}$ to produce a $\mathrm{TiO}_{2}$ film on the $\mathrm{Si}$ and $\mathrm{HF}$ in the solution. The formation of $\mathrm{HF}$ prohibits the growth of $\mathrm{TiO}_{2}$. At this moment, the $\mathrm{H}_{3} \mathrm{BO}_{3}$ consumes $\mathrm{HF}$, thereby sustaining the growth of $\mathrm{TiO}_{2}$. The grown $\mathrm{TiO}_{2}$ was then rinsed in deionized water and was air-dried with purified nitrogen. After $\mathrm{TiO}_{2}$ deposition, a thin layer of B-doped a-Si:H $(20 \mathrm{~nm})$ was deposited through PECVD $(13.56 \mathrm{MHz})$. A transparent conductor, indium-tin oxide (ITO), was then deposited through sputtering in a 80-nm-thick layer. Subsequently, front and back contacts, namely $\mathrm{Ag}(100 \mathrm{~nm})$ and $\mathrm{Al}(200 \mathrm{~nm})$, respectively, were deposited using a thermal evaporator. The dark current density-voltage characteristics of the fabricated solar cells were measured using an Agilent B2912A semiconductor parameter analyzer, and the photovoltaic characteristics were measured using the same setup equipped with a calibrated solar simulator under an air mass (AM) $1.5 \mathrm{G}\left(100 \mathrm{~mW} / \mathrm{cm}^{2}\right)$ condition. The external quantum efficiency (EQE) was measured 
using a Titan Electro-Optics QE-3000 system (Titan Electro-Optics Co., Taipei, Taiwan). Scanning electron microscopy (SEM) images were taken using a JEOL JSM-6700F (JEOL USA Inc., Peabody, MA, USA). Transmission electron microscopy (TEM) measurements were obtained using a JEOL JEM-2100F (JEOL USA Inc.). X-ray photoelectron spectroscopy (XPS) measurement was performed using a ULVAC-PHI PHI 5000 Versa Probe (Physical Electronics, Inc., Chanhassen, MN, USA).

\section{Results and Discussion}

To determine the proper band alignment to n-type Si for carrier selection, ultraviolet (UV) photoemission spectroscopy (UPS) was performed to measure the energy levels of $\mathrm{TiO}_{2}$ [20]. The UPS was performed by emitting UV photons with an energy of $21.2 \mathrm{eV}$ to the $\mathrm{TiO}_{2}$ film. The binding energy (BE) of photoelectrons was analyzed. A schematic of the mechanism is plotted in Figure 1a.

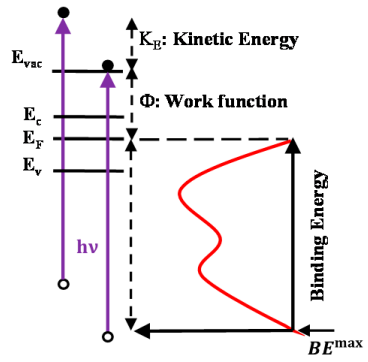

(a)

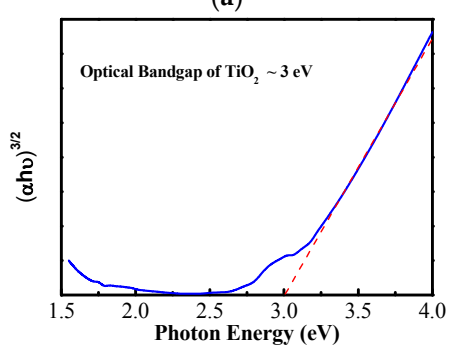

(c)

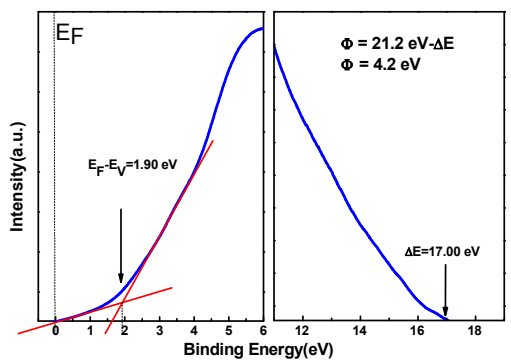

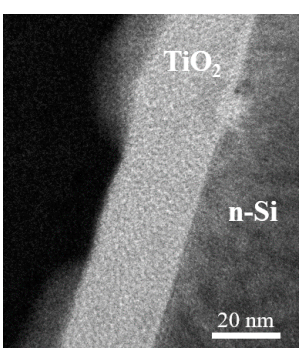

(d) (b)

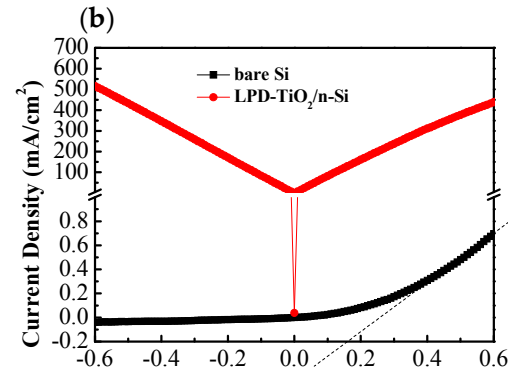

(e)

Figure 1. (a) Schematic of work function of $\mathrm{TiO}_{2}$ determined through ultraviolet (UV) photoemission spectroscopy (UPS) spectroscopy; (b) UPS spectrum of liquid phase deposition (LPD)- $\mathrm{TiO}_{2}$; (c) optical bandgap of $\mathrm{TiO}_{2}$ layer; (d) image of $\mathrm{TiO}_{2} / \mathrm{Si}$ interface taken through transmission electron microscopy (TEM); and (e) $I-V$ characteristics of $\mathrm{Al} / \mathrm{LPD}-\mathrm{TiO}_{2} / \mathrm{Si}$ diode.

The Fermi energy $\left(E_{\mathrm{F}}\right)$ of the solution-processed $\mathrm{TiO}_{2}$ is suggested to have an energy level between the conduction band edge $\left(E_{\mathrm{C}}\right)$ and the valence band edge $\left(E_{\mathrm{V}}\right)$ of the $\mathrm{TiO}_{2}$. Upon UV light illumination, valence electrons are excited and escape from the associated atoms with a kinetic energy $(K E)$ measured by a detector. Therefore, the energy relationship of the system can be described by $B E=h v-K E-\Phi$, in which $B E$ is the binding energy of an electron, determined as the difference between the energy of the electron in the valence band and the $E_{\mathrm{F}} ; \mathrm{h} v$ is the energy of the UV light; and $\Phi$ is the work function of the system, determined as the energy difference between the vacuum level and the $\mathrm{E}_{\mathrm{F}}$. Therefore, a $B E$ was obtained at each KE. The maximum $B E$ was obtained at zero $K E$, as shown in Figure $1 b$. The work function $(\Phi)$ of the films was defined by $\Phi=h v-\Delta E$, in which $\Delta E$ is determined as the $B E$ at the cutoff edge of electron emission [20,21]. Extrapolation shows that the cutoff edge is $17 \mathrm{eV}$. Therefore, the work function is $4.2 \mathrm{eV}$ in the $\mathrm{LPD}$-grown $\mathrm{TiO}_{2}$ film. The energy difference between $E_{\mathrm{F}}$ and $E_{\mathrm{V}}$ can be determined at the rising point of electron emission through extrapolation, because the electrons are occupied mostly in the valence band in a semiconductor. The calculated $E_{\mathrm{F}}-E_{\mathrm{V}}$ difference is $1.9 \mathrm{eV}$. Accordingly, the $E_{\mathrm{V}}$ is $6.1 \mathrm{eV}$ below the vacuum level. The transmission spectrum of $\mathrm{TiO}_{2}$-grown glass was used to calculate the bandgap $(E \mathrm{~g})$ of the $\mathrm{TiO}_{2}$ through the following procedure. The absorbance (A) of the $\mathrm{TiO}_{2}$ layer can be obtained using the relation $A=1-R-T$, in which $R$ is the reflectance, and 
$T$ is the transmittance. With known thickness $(d)$ and $A$, the absorption coefficient $(\alpha)$ can be deduced according to the relation $A=\exp (-\alpha d)$. With the absorption coefficient, the optical bandgap of the $\mathrm{TiO}_{2}$ can be obtained according to a Tauc plot, as shown in Figure 1c. The optical bandgap of the $\mathrm{TiO}_{2}$ was determined to be $3 \mathrm{eV}$ through this method. Accordingly, the $E_{\mathrm{C}}$ is $3.1 \mathrm{eV}$ from the vacuum level. In general, the $E_{\mathrm{C}}$ and $E_{\mathrm{V}}$ for $\mathrm{Si}$ are $4.05 \mathrm{eV}$ and $5.17 \mathrm{eV}$, respectively. Therefore, the valence band barrier for the $\mathrm{TiO}_{2} / \mathrm{Si}$ interface is $0.93 \mathrm{eV}$.

A high-resolution TEM image of the grown $\mathrm{TiO}_{2}$ on crystalline $\mathrm{Si}$ is depicted in Figure 1d. The $\mathrm{TiO}_{2}$ layer is approximately 24-nm-thick. The TEM images confirm that the solution-processed $\mathrm{TiO}_{2}$ was smoothly deposited on the $\mathrm{Si}$ surface. To examine the ability of holes to tunnel through $\mathrm{TiO}_{2}$, an $\mathrm{Al} / \mathrm{TiO}_{2} / \mathrm{Si}$ diode structure was used to measure the $I-V$ characteristics, as shown in Figure 1e. The current density, as high as $100 \mathrm{~mA} / \mathrm{cm}^{2}$, was obtained at a low voltage in the $\mathrm{Al} / \mathrm{TiO}_{2} / \mathrm{Si}$ diode under both positive and negative biases, indicating that both electrons and holes can flow through the 24-nm-thick $\mathrm{TiO}_{2}$ efficiently without being blocked. The energy levels were measured through UPS as described. By contrast, without $\mathrm{TiO}_{2}, \mathrm{Al} / \mathrm{n}-\mathrm{Si}$ exhibits a Schottky diode behavior [15] with a Schottky barrier height of $0.157 \mathrm{eV}$, as shown in Figure 1e.

To identify the reason for the efficient hole tunneling, the chemical structure of $\mathrm{TiO}_{2}$ was explored through XPS. Figure 2a shows the atomic concentration depth profile for a thick $\mathrm{TiO}_{2}$ film. Clear Ti and $\mathrm{Si}$ intermixing at the surface is evident. To further study the interface, the BE spectra of Ti 2p, O 1s, and Si $2 p$ signals at the interface were analyzed and are shown in Figure $2 b-d$, respectively. After deconvolution, the Ti $2 \mathrm{p} 2 \mathrm{p} 3 / 2$ spectra have three peaks, which are associated with $\mathrm{TiO}(454.7 \mathrm{eV})$, $\mathrm{Ti}_{2} \mathrm{O}_{3}(457 \mathrm{eV})$, and $\mathrm{TiO}_{2}(458.7 \mathrm{eV})$ [22], indicating that oxygen is deficient in the $\mathrm{TiO}_{2}$ film. The O1s spectra also have three peaks, which are associated with $\mathrm{TiO}_{2}(530.3 \mathrm{eV})$, oxygen-deficient $\mathrm{TiO}_{2}$ $(531.1 \mathrm{eV})$, and $\mathrm{SiO}_{2}(532.2 \mathrm{eV})$ [22,23]. The oxygen deficiency implies the existence of Ti dangling bonds, which cause gap states in the $\mathrm{LPD}-\mathrm{TiO}_{2}$ film. These gap states stimulate trap-assisted tunneling (TAT), which ensures that the photogenerated holes in $\mathrm{Si}$ are transported through the $\mathrm{TiO}_{2}$ to the ITO anode. The Si2p spectra have two peaks, which are associated with $\mathrm{Si}(99 \mathrm{eV})$ and $\mathrm{Si}-\mathrm{O}(102 \mathrm{eV})[23,24]$. The presence of $\mathrm{Si}-\mathrm{O}$ bonding indicates that small amounts of $\mathrm{SiO}_{2}$ exist inside the $\mathrm{TiO}_{2}$ or at the $\mathrm{Si}$ surface. The incorporation of $\mathrm{Si}$ is an essential property of $\mathrm{LPD}$-grown $\mathrm{TiO}_{2}$ film. The $\mathrm{Si}$ dissolves into the solution through HF etching during $\mathrm{LPD}$ of $\mathrm{TiO}_{2}$. The dissolved $\mathrm{Si}$ then forms either Ti-O-Si or $\mathrm{Si}-\mathrm{O}$ bonds at the $\mathrm{TiO}_{2} / \mathrm{Si}$ interface. The coexistence of oxygen-deficient $\mathrm{Ti}$ and $\mathrm{Si}$ bonding and oxygen-bridging $\mathrm{Ti}$ and $\mathrm{Si}$ bonding may be responsible for the reduction of the measured barrier height for holes between $\mathrm{Si}$ and $\mathrm{LPD}-\mathrm{TiO}_{2}$.

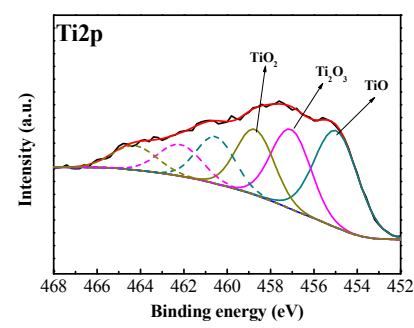

(a)

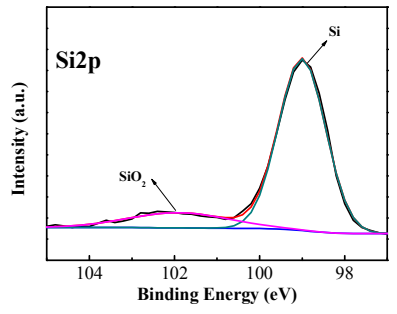

(c)

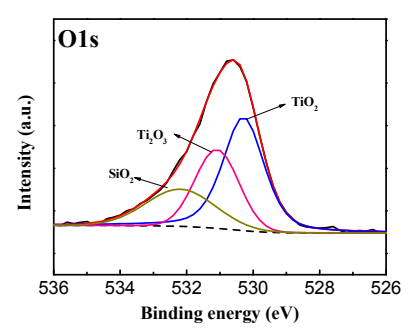

(b)

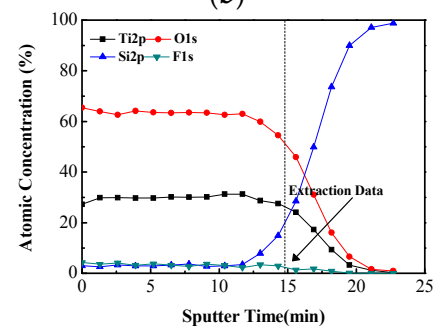

(d)

Figure 2. (a) Ti 2p; (b) O 1s; (c) Si 2p core level atomic structures for $\mathrm{LPD}^{-\mathrm{TiO}_{2}}$ obtained through X-ray photoelectron spectroscopy (XPS); and (d) depth profiles of these signals. 
Figure 3a shows a schematic of band alignment in a fabricated heterojunction solar cell based on UPS measurement. According to the band alignment, the photogenerated electrons and holes are transported to the cathode and anode, respectively, by the established electrical field. The holes are probably blocked by barriers set by the $\mathrm{TiO}_{2}$. However, the experimental observations indicated that holes can flow through such barriers, as shown in Figure 1d. A mechanism of TAT through the gap states in $\mathrm{TiO}_{2}$ was proposed to be responsible for the high tunneling rate of holes. The physical theorem and calculation relevant to TAT have been discussed [25-29]. A multiple trap center model was used to simulate the tunneling current in the $\mathrm{SiO}_{2}$. The current density attained through multiple-TAT was calculated to be approximately 8 orders of magnitude higher than the current density achieved through direct tunneling for 4.5-nm-thick $\mathrm{SiO}_{2}$. In addition, the multiple-TAT current gradually decreases as the $\mathrm{SiO}_{2}$ thickness increases. The carrier behavior in the valence band around $\mathrm{TiO}_{2}$ based on this model is illustrated in Figure 3b.

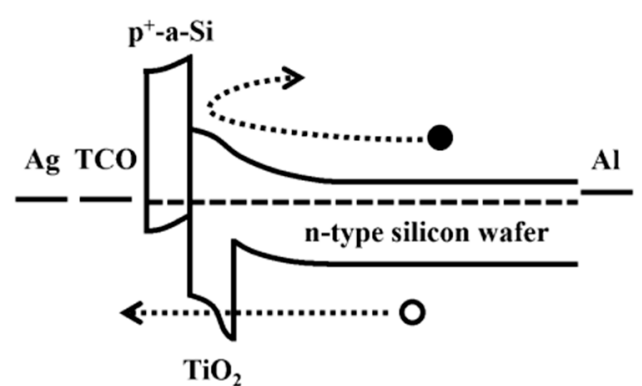

(a)

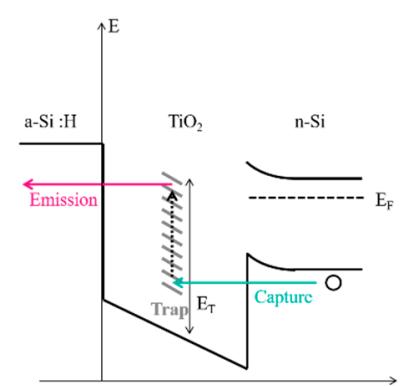

(b)

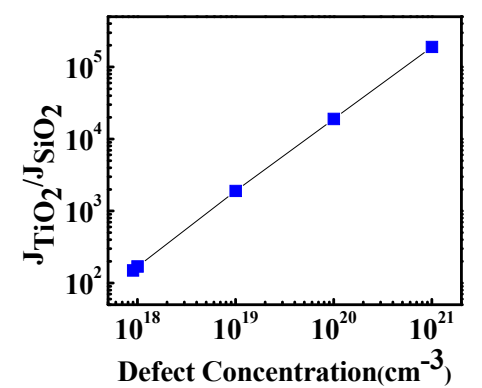

(c)

Figure 3. (a) Band alignment of proposed $\mathrm{TiO}_{2} / \mathrm{Si}$ heterojunction solar cell; (b) enlarged part of band diagram at $E_{\mathrm{V}}$ around interface of $\mathrm{TiO}_{2} / \mathrm{Si}$; and (c) ratio of tunneling current through $\mathrm{TiO}_{2}$ to that through $\mathrm{SiO}_{2}\left(J_{\mathrm{TiO} 2} / J_{\mathrm{SiO} 2}\right)$ according to gap state concentration.

When holes become close to $\mathrm{TiO}_{2}$, they are captured by traps (gap states) and then emitted to a-Si:H by the internal field. Therefore, the capture rate $\left(R_{\mathrm{ci}}\right)$ and emission rate $\left.\left(R_{\mathrm{ei}}\right)\right)$ are dominant factors influencing the tunneling current. The current density can be expressed as the sum of the capture and emission rates $R_{i}$ in each trap multiplied by the trap cross section $\Delta \chi_{i}$, as shown in Equation (3).

$$
\mathrm{J}=\mathrm{q} \sum_{i} R_{i} \Delta \mathrm{x}_{i}
$$

Under a high internal field, the carriers must tunnel through the $\mathrm{TiO}_{2}$, and the emission rate must be higher or equal to the capture rate. Therefore, the calculation focuses on the emission rate. The emission rate can be expressed as the emission lifetime multiplied by the density of gap states, as shown in Equation (4). Furthermore, the emission lifetime can also be expressed by the relationship between the carrier distribution probability and the effective mass and energy levels, as shown in Equation (5). Finally, the tunneling current can be expressed by Equations (3) and (4) as expressed in Equation (6).

$$
\begin{aligned}
& R_{\mathrm{ei}} \propto \tau_{\mathrm{ei}}{ }^{-1} \times N_{\mathrm{ti}} \propto \frac{1}{\left(m_{\text {diel }}\right)^{2} \times E_{\mathrm{T}} \times E_{\mathrm{g}}} \exp \left[-\left(E-E_{\mathrm{T}}\right)\right] \times N_{\mathrm{ti}} \\
& \tau_{\mathrm{ei}}{ }^{-1} \propto \frac{1}{\left(m_{\text {diel }}\right)^{2} \times E_{\mathrm{T}} \times E_{\mathrm{g}}} \exp \left[-\left(E-E_{\mathrm{T}}\right)\right] \\
& J \propto \frac{1}{\left(m_{\text {diel }}\right)^{2} \times E_{\mathrm{T}} \times E_{\mathrm{g}}} \exp \left[-\left(E-E_{\mathrm{T}}\right)\right] \times N_{\mathrm{ti}} \times \frac{1}{\sqrt{m_{\text {diel }} \times E_{\mathrm{T}}}}
\end{aligned}
$$

In the preceding equations, $m_{\text {diel }}$ is the effective hole mass (approximately $0.71 m_{0}$ ) in the dielectric, $E_{\mathrm{T}}$ is the $E_{\mathrm{V}}$ of $\mathrm{TiO}_{2}, \tau_{\mathrm{ei}}{ }^{-1}$ is the emission lifetime, and $N_{\mathrm{ti}}$ is the gap state concentration in the $\mathrm{TiO}_{2}$. On the basis of these equations, we can calculate the ratio of the tunneling current density in the $\mathrm{TiO}_{2}$ to 
that in the $\mathrm{SiO}_{2}$ at different gap state concentrations. In this calculation, the gap state density for $\mathrm{SiO}_{2}$ is fixed at $9 \times 10^{17} \mathrm{~cm}^{3}$, as described in the literature [27]. This ratio is shown in Figure 3c. According to Figure 3c, at the same gap state density, the tunneling current through $\mathrm{TiO}_{2}$ is more than 100 times higher than that through $\mathrm{SiO}_{2}$. With an increase of the gap state density in the $\mathrm{TiO}_{2}$ to $10^{21} \mathrm{~cm}^{3}$, the tunneling current ratio becomes higher than $10^{5}$. Such a high gap state density is reasonable. An oxygen-deficient signal was evident in XPS for $\mathrm{TiO}$, and $\mathrm{Ti}_{2} \mathrm{O}_{3}$ occupied approximately two thirds of the Ti signal, whereas stoichiometric $\mathrm{TiO}_{2}$ occupied only approximately one third. Therefore, chemically grown $\mathrm{TiO}_{2}$ can withstand a high hole tunneling rate without blocking the holes.

The dark and photocurrent-voltage characteristics are illustrated in Figure 4a,b, respectively. All solar cells with a $\mathrm{TiO}_{2}$ layer ranging from $24 \mathrm{~nm}$ to $48 \mathrm{~nm}$ in thickness exhibit favorable junction behavior. The rectifier ratio calculated at $0.5 \mathrm{~V}$ is approximately 7500 for a device with 24-nm-thick $\mathrm{TiO}_{2}$. Other devices have similar values. The ideal factors for solar cells with 24-, 32-, 40-, and 48-nm-thick $\mathrm{TiO}_{2}$ layers are $1.63,1.75,1.71$, and 1.45 , respectively. Such moderate ideal factors indicate that carrier recombination is not high at the $\mathrm{TiO}_{2} / \mathrm{Si}$ interface. However, if the $\mathrm{TiO}_{2}$ layer is absent in the heterojunction solar cell, the reverse saturation current clearly increases. The reverse saturation current density, $J_{0}$, for a reference device (without $\mathrm{TiO}_{2}$ ) is $7.12 \times 10^{-7} \mathrm{~A} / \mathrm{cm}^{2}$, and it is $3.54 \times 10^{-7} \mathrm{~A} / \mathrm{cm}^{2}$ for a device with 24-nm-thick $\mathrm{TiO}_{2}$. In addition, the reference device exhibits a relatively high ideal factor $(>2)$ at a forward voltage. These findings indicate that $\mathrm{TiO}_{2}$ can properly passivate the interface between a-Si:H and $\mathrm{Si}$ as well as further improve the electrical contact behavior between them.

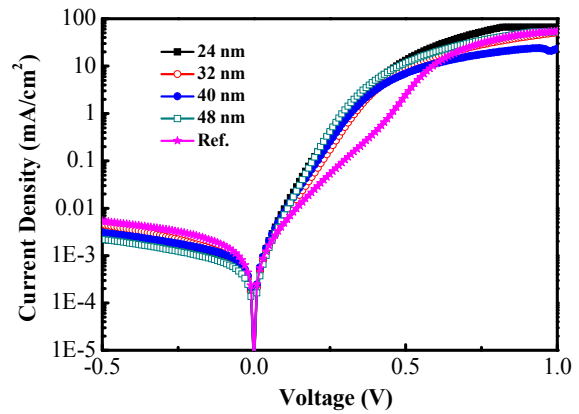

(a)

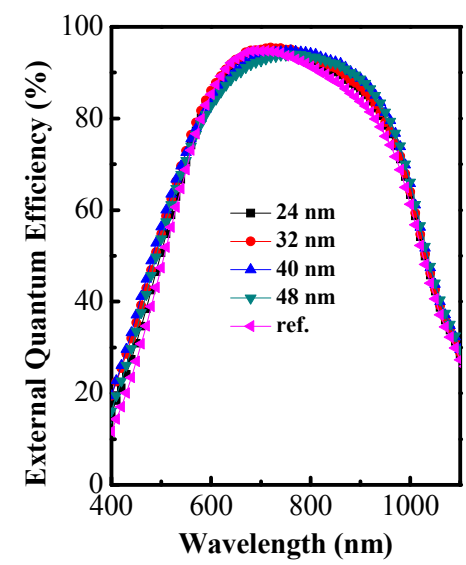

(c)

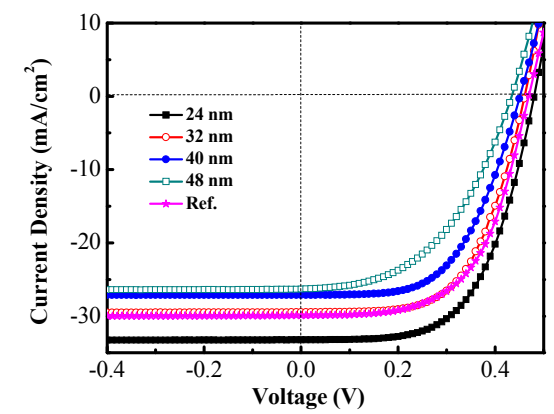

(b)

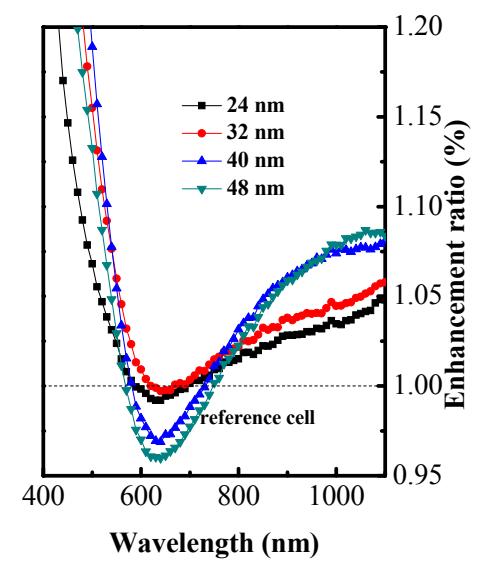

(d)

Figure 4. Photocurrent-voltage characteristics for heterojunction solar cells containing $\mathrm{TiO}_{2}$ at different thicknesses: (a) dark $I-V$ characteristics; (b) photocurrent-voltage characteristics obtained under AM 1.5G; (c) external quantum efficiency (EQE) of solar cells; and (d) ratio of EQE enhancement of solar cells with $\mathrm{TiO}_{2}$ interlayer relative to the reference cell.

The photocurrent-voltage characteristics of heterojunction solar cells with and without $\mathrm{TiO}_{2}$, measured under an AM $1.5 \mathrm{G}\left(100 \mathrm{~mW} / \mathrm{cm}^{2}\right)$ illumination condition by using a calibrated solar 
simulator, are illustrated in Figure $4 \mathrm{~b}$. The short-circuit current density $\left(J_{\mathrm{sc}}\right)$, open-circuit voltage $\left(V_{\text {oc }}\right)$, and fill factor for a heterojunction solar cell with $\mathrm{TiO}_{2}(24 \mathrm{~nm})$ are $33.2 \mathrm{~mA} / \mathrm{cm}^{2}, 0.49 \mathrm{~V}$, and 0.579 , respectively, yielding a power conversion efficiency (PCE) of 9.42. By contrast, without a $\mathrm{TiO}_{2}$ interlayer, the values of those solar cell performance indicators are $29.9 \mathrm{~mA} / \mathrm{cm}^{2}, 0.47 \mathrm{~V}$, and 0.586 , yielding an $8.23 \%$ PCE. The enhanced performance is attributed to the properly aligned and passivated interfaces for hole tunneling between a-Si:H and $\mathrm{Si}$ achieved by inserting the $\mathrm{TiO}_{2}$ layer.

The $J_{\mathrm{sc}}$ is quite high for a planar solar cell containing no surface microstructure for light harvesting. As the thickness of $\mathrm{TiO}_{2}$ is increased to $48 \mathrm{~nm}$, the $J_{\mathrm{sc}}$ decreases gradually to $26.3 \mathrm{~mA} / \mathrm{cm}^{2}$. This implies that the PCE also gradually decreases, reaching $5.52 \%$ for a solar cell with 48 -nm-thick $\mathrm{TiO}_{2}$. The details are listed in Table 1 . This reduction is inversely proportional to the increase in the series resistance. Consequently, the reduction of the $J_{\mathrm{sc}}$ was attributed to slight current blocking by the thicker $\mathrm{TiO}_{2}$. The EQE of several fabricated solar cells is shown in Figure 4c. The solar cells with a $\mathrm{TiO}_{2}$ interlayer ( $24 \mathrm{~nm}$ and $32 \mathrm{~nm}$ ) exhibit higher EQE than that of the solar cell without a $\mathrm{TiO}_{2}$ interlayer (reference) in both the short wavelength $(400-580 \mathrm{~nm})$ and near infrared $(750-1100 \mathrm{~nm})$ ranges. The enhanced EQE for the solar cells with a $\mathrm{TiO}_{2}$ interlayer indicates the probability of passivation at interfaces. It also indicates that the solar cells with a $\mathrm{TiO}_{2}$ interlayer may establish a higher internal electrical field than that of the reference cell inside the n-Si. Notably, the EQE of solar cells with thicker $\mathrm{TiO}_{2}$ interlayers ( $40 \mathrm{~nm}$ and $48 \mathrm{~nm}$ ) is lower than that of the reference cell at $580-750 \mathrm{~nm}$. This phenomenon is clearly explained by the enhancement ratio, which is expressed as the EQE of a solar cell with a $\mathrm{TiO}_{2}$ interlayer divided by the EQE of the reference cell. Figure $4 \mathrm{~d}$ depicts the enhancement ratio for four samples; the EQE of solar cells with thicker $\mathrm{TiO}_{2}$ interlayers $(40 \mathrm{~nm}$ and $48 \mathrm{~nm}$ ) is $95 \%$ of the EQE of the reference cell. This may be attributed to slight carrier blocking by the $\mathrm{TiO}_{2}$. The calculated $J_{\mathrm{sc}}$ is listed in Table 1 and denoted by $J_{\mathrm{sc}}(\mathrm{EQE})$. The measured $J_{\mathrm{sc}}$ and $J_{\mathrm{sc}}(\mathrm{EQE})$ are highly similar for the reference sample. By contrast, the $J_{\mathrm{sc}}$ (EQE) for the solar cell with a 24-nm-thick $\mathrm{TiO}_{2}$ interlayer is lower than that of the measured $J_{\mathrm{sc}}$. This may be due to the difference in the measurement setup between the solar simulator and the quantum efficiency spectrometer. However, the $J_{\mathrm{sc}}$ (EQE) also shows a decreasing trend as the $\mathrm{TiO}_{2}$ thickness increases, which is consistent with the proposed mechanism. The PCE based on $J_{\mathrm{sc}}(\mathrm{EQE})$ is also listed in Table 1.

Table 1. Photovoltaic characteristics of $\mathrm{TiO}_{2} / \mathrm{Si}$ heterojunction solar cells.

\begin{tabular}{cccccc}
\hline Parameter & Ref. $^{\text {a }}$ & $\mathbf{2 4} \mathbf{~ n m}$ & $\mathbf{3 2} \mathbf{~ n m}$ & $\mathbf{4 0} \mathbf{~ m m}$ & $\mathbf{4 8} \mathbf{~ n m}$ \\
\hline$V_{\mathrm{oc}}(\mathrm{V})$ & 0.47 & 0.49 & 0.47 & 0.46 & 0.44 \\
$J_{\mathrm{sc}}\left(\mathrm{mA} / \mathrm{cm}^{2}\right)$ & 29.9 & 33.2 & 29.5 & 27.1 & 26.3 \\
$J_{\mathrm{sc}}(\mathrm{EQE})\left(\mathrm{mA} / \mathrm{cm}^{2}\right)$ & 30.5 & 31.77 & 31.88 & 31.42 & 30.59 \\
Fill Factor & 0.586 & 0.579 & 0.583 & 0.556 & 0.477 \\
Efficiency $(\%)$ & 8.23 & 9.42 & 8.09 & 6.93 & 5.52 \\
Efficiency EQE $(\%)$ & 8.40 & 9.01 & 8.73 & 7.98 & 6.42 \\
$R_{\mathrm{s}}\left(\Omega-\mathrm{cm}^{2}\right)$ & 3.8 & 3 & 3.5 & 4.44 & 5.35 \\
$R_{\mathrm{sh}}\left(\Omega-\mathrm{cm}^{2}\right)$ & 1855 & 1875 & 1727 & 11,875 & 5369 \\
\hline \multicolumn{5}{c}{ a p-a-Si:H/n-Si heterojunction solar cell. }
\end{tabular}

The reduction in the barrier height and the ease of tunneling for carriers through the $\mathrm{TiO}_{2} / \mathrm{Si}$ interface can only ensure that the photocarrier is collected. They do not increase the light harvesting ability. To identify the reason for the high photocurrent $\left(33.2 \mathrm{~mA} / \mathrm{cm}^{2}\right)$ obtained in the LPD-grown $\mathrm{TiO}_{2}$ heterojunction solar cell based on a polished Si substrate, the surface morphology of LPD-grown $\mathrm{TiO}_{2}$ on $\mathrm{Si}$ was characterized through SEM.

Figure 5a depicts plan-view SEM images of the LPD-grown $\mathrm{TiO}_{2}$ with different thicknesses. Many randomly arranged circular protrusions in a moth-eye-like structure were found over the LPD-TiO surface. The density of these structures increases as the $\mathrm{TiO}_{2}$ thickness increases. The diameter for each structure is approximately $100 \mathrm{~nm}$. This dimension is close to the quarter wavelength of visible light in $\mathrm{TiO}_{2}$. Therefore, the interaction of incident light and LPD-grown $\mathrm{TiO}_{2}$ can be expressed by 
Mie scattering [30-32]. In the mechanism of Mie scattering, the percentage of back scattering is lower than that of Rayleigh scattering. Therefore, most of the incident light can be coupled into Si with high deflection. The deflected light can be reflected back and forth many times inside $\mathrm{Si}$, increasing the absorbance of the incident light. This scattering mechanism is illustrated in Figure $5 \mathrm{~b}$. The reflectance of the $\mathrm{LPD}$-grown $\mathrm{TiO}_{2}$ on $\mathrm{Si}$ at $300-800 \mathrm{~nm}$ is shown in Figure $5 \mathrm{c}$. In the figure, thick $\mathrm{TiO}_{2}$ exhibits lower reflectance than that of thin $\mathrm{TiO}_{2}$, indicating that the incident light is more intense for the thick $\mathrm{TiO}_{2}$. However, the solar cell with the thick $\mathrm{TiO}_{2}$ exhibits a lower $J_{\mathrm{sc}}$ than that of the solar cell with the thin $\mathrm{TiO}_{2}$. Therefore, as the $\mathrm{TiO}_{2}$ thickness increases, hole transport through $\mathrm{TiO}_{2}$ to the anode becomes less easy, causing the current density to decrease. Consequently, the improved performance of the device is due to the enhanced hole transport rather than increased light trapping.

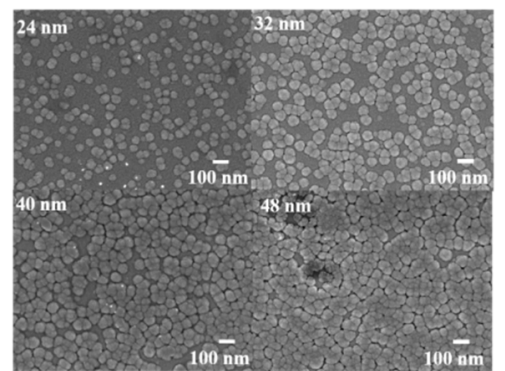

(a)

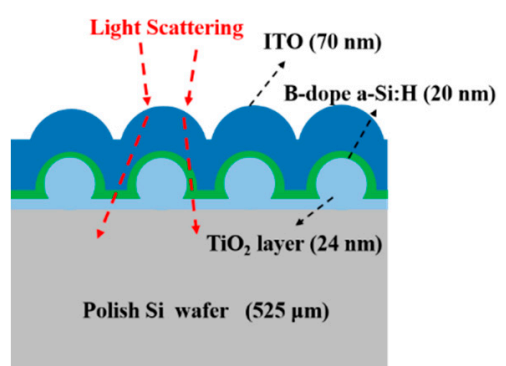

(b)

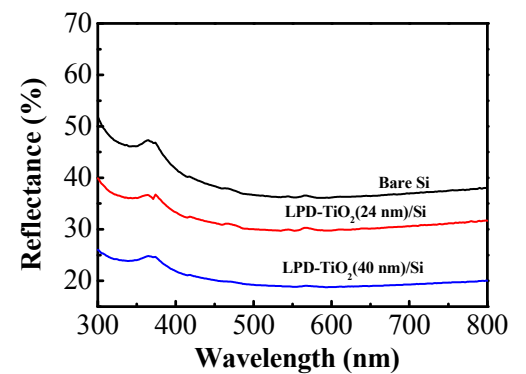

(c)

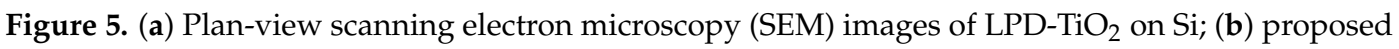
light scattering process in $\mathrm{TiO}_{2}$ solar cell. The inset of (c) shows the measured surface reflectance of planar $\mathrm{Si}$ and $\mathrm{LPD}-\mathrm{TiO}_{2}$ on $\mathrm{Si}$.

\section{Conclusions}

In conclusion, we demonstrated enhancements in Si-based heterojunction solar cells fabricated using a low temperature and liquid-phase-processed $\mathrm{TiO}_{2}$. LPD enables high throughput and low cost solar cell production. The $\mathrm{LPD}-\mathrm{TiO}_{2}$ can passivate the $\mathrm{Si}$ surface, preventing plasma and chemical damage in subsequent processes. Through UPS investigation, the work function, $E_{\mathrm{C}}$, and $E_{\mathrm{V}}$ for $\mathrm{LPD}^{-\mathrm{TiO}_{2}}$ were obtained. The band alignment indicates that electrons and holes could be collected properly. On the polished $\mathrm{Si}$ substrate, a $33.2-\mathrm{mA} / \mathrm{cm}^{2}$ short-circuit current was obtained. A moth-eye-like structure was observed on the LPD-grown $\mathrm{TiO}_{2}$ surface. Mie scattering in these structures ensures light harvesting and is responsible for the high photocurrent.

Acknowledgments: This work was financially supported by the Ministry of Science and Technology of Taiwan under MOST grant nos. MOST 104-2221-E-005-074.

Author Contributions: Yu-Tsu Lee and Zingway Pei conceived and designed the experiments; Fang-Ru Lin and Ting-Chun Lin performed the experiments; Yu-Tsu Lee and Zingway Pei analyzed the data; Chien-Hsun Chen contributed in a-Si:H deposition and efficiency measurement; Yu-Tsu Lee and Zingway Pei wrote the paper.

Conflicts of Interest: The authors declare no conflict of interest.

\section{References}

1. Kang, H.; Kim, G.; Hwang, I.W.; Kim, Y.; Lee, K.C.; Park, S.H.; Lee, K. High-performance polymer tandem devices combining solar cell and light-emitting diode. Sol. Energy Mater. Sol. Cells 2012, 107, $148-153$. [CrossRef]

2. Morteani, A.C.; Dhoot, A.S.; Kim, J.S.; Silva, C.; Greenham, N.C.; Murphy, C.; Moons, E.; Cina, S.; Burroughes, J.H.; Friend, R.H. Barrier-free electron-hole capture in polymer blend heterojunction light-emitting diodes. Adv. Mater. 2003, 15, 1708-1712. [CrossRef]

3. Chen, C.P.; Ke, M.Y.; Liu, C.C.; Chang, Y.J. Observation of $394 \mathrm{~nm}$ electroluminescence from low-temperature sputtered $\mathrm{n}-\mathrm{ZnO} / \mathrm{SiO}_{2}$ thin films on top of the $\mathrm{p}-\mathrm{GaN}$ heterostructure. Appl. Phys. Lett. 2007, 91. [CrossRef] 
4. You, J.B.; Zhang, X.W.; Zhang, S.G.; Wang, J.X.; Yin, Z.G.; Tan, H.R.; Zhang, W.J.; Chu, P.K.; Cui, B.; Wowchak, A.M.; et al. Improved electroluminescence from n-ZnO/AlN/p-GaN heterojunction light-emitting diodes. Appl. Phys. Lett. 2010, 96. [CrossRef]

5. $\quad$ Liang, H.K.; Yu, S.F.; Yang, H.Y. Directional and controllable edge-emitting ZnO ultraviolet random laser diodes. Appl. Phys. Lett. 2010, 96. [CrossRef]

6. Zhu, H.; Shan, C.X.; Yao, B.; Li, B.H.; Zhang, J.Y.; Zhang, Z.Z.; Zhao, D.X.; Shen, D.Z.; Fan, X.W.; Lu, Y.M.; et al. Ultralow-threshold laser realized in zinc oxide. Adv. Mater. 2009, 21, 1613-1617. [CrossRef]

7. Wang, D.Y.; Jiang, Y.T.; Lin, C.C.; Li, S.S.; Wang, Y.T.; Chen, C.C.; Chen, C.W. Solution-processable pyrite fes 2 nanocrystals for the fabrication of heterojunction photodiodes with visible to NIR photodetection. Adv. Mater. 2012, 24, 3415-3420. [CrossRef] [PubMed]

8. Shao, D.; Yu, M.; Lian, J.; Sawyer, S. Heterojunction photodiode fabricated from hydrogen treated $\mathrm{ZnO}$ nanowires grown on p-silicon substrate. Appl. Phys. Lett. 2012, 101. [CrossRef] [PubMed]

9. Shao, D.; Yu, M.; Lian, J.; Sawyer, S. Heterojunction photodiode fabricated from multiwalled carbon nanotube/ZnO nanowire/p-silicon composite structure. Appl. Phys. Lett. 2013, 102. [CrossRef]

10. Wolf, S.D.; Descoeudres, A.; Holman, Z.C.; Ballif, C. High-efficiency silicon heterojunction solar cells: A review. Green 2012, 2, 7-24. [CrossRef]

11. Pudasaini, P.R.; Zepeda, F.R.; Sharma, M.; Elam, D.; Ponce, A.; Ayon, A.A. High Efficiency Hybrid Silicon Nanopillar-Polymer Solar Cells. ACS Appl. Mater. Interfaces 2013, 5, 9620-9627. [CrossRef] [PubMed]

12. Pudasaini, P.R.; Elam, D.; Ayon, A.A. Aluminum oxide passivated radial junction sub-micrometre pillar array textured silicon solar cells. J. Phys. D Appl. Phys. 2013, 46. [CrossRef]

13. Pudasaini, P.R.; Sharma, M.; Zepeda, F.R.; Ayon, A.A. Efficiency improvement of a nanostructured polymer solar cell employing atomic layer deposited $\mathrm{Al}_{2} \mathrm{O}_{3}$ as a passivation layer. Microelectron. Eng. 2014, 119, 6-10. [CrossRef]

14. Sheng, J.; Fan, K.; Wang, D.; Han, C.; Fang, J.; Gao, P.; Ye, J. Improvement of the $\mathrm{SiO}_{x}$ passivation layer for high-efficiency Si/PEDOT:PSS heterojunction solar cells. Appl. Mater. Interfaces 2014, 6, 16027-16034. [CrossRef] [PubMed]

15. Neamen, D.A. Semiconductor Physics and Devices, 4th ed.; McGraw-Hill: New York, NY, USA, 2012.

16. Avasthi, S.; McClain, W.E.; Man, G.; Kahn, A.; Schwartz, J.; Sturm, J.C. Hole-blocking titanium-oxide/silicon heterojunction and its application to photovoltaics. Appl. Phys. Lett. 2013, 102. [CrossRef]

17. Salim, T.; Yin, Z.; Sun, S.; Huang, X.; Zhang, H.; Lam, Y.M. Solution-processed nanocrystalline $\mathrm{TiO}_{2}$ buffer layer used for improving the performance of organic photovoltaics. ACS Appl. Mater. Interfaces 2011, 3, 1063-1067. [CrossRef] [PubMed]

18. Richards, B.S.; Cotter, J.E.; Honsberg, C.B. Enhancing the surface passivation of $\mathrm{TiO}_{2}$ coated silicon wafers. Appl. Phys. Lett. 2002, 80. [CrossRef]

19. Lee, M.K.; Lee, H.C.; Hsu, C.M. High dielectric constant $\mathrm{TiO}_{2}$ film grown on polysilicon by liquid phase deposition. Mater. Sci. Semicond. Process. 2007, 10, 61-67. [CrossRef]

20. Li, C.Y.; Wen, T.C.; Lee, T.H.; Guo, T.F.; Huang, J.C.A.; Lind, Y.C.; Hsu, Y.J. An inverted polymer photovoltaic cell with increased air stability obtained by employing novel hole/electron collecting layers. J. Mater. Chem. 2009, 19, 1643-1647. [CrossRef]

21. Ishii, H.; Sugiyama, K.; Ito, E.; Seki, K. Energy level alignment and interfacial electronic structures at organic/metal and organic/organic interfaces. Adv. Mater. 1999, 11, 605-625. [CrossRef]

22. Fang, Q.; Meier, M.; Yu, J.J.; Wang, Z.M.; Zhang, J.Y.; Wu, J.X.; Kenyon, A.; Hoffmann, P.; Boyd, I.W. FTIR and XPS investigation of Er-doped $\mathrm{SiO}_{2}-\mathrm{TiO}_{2}$ films. Mater. Sci. Eng. B 2003, 105, 209-213. [CrossRef]

23. Anandan, C.; Bera, P. XPS studies on the interaction of $\mathrm{CeO}_{2}$ with silicon in magnetron sputtered $\mathrm{CeO}_{2}$ thin films on $\mathrm{Si}$ and $\mathrm{Si}_{3} \mathrm{~N}_{4}$ substrates. Appl. Surf. Sci. 2013, 283, 297-303. [CrossRef]

24. Zhang, W.; Zhang, S.; Liu, Y.; Chen, T. Evolution of Si suboxides into Si nanocrystals during rapid thermal annealing as revealed by XPS and Raman studies. J. Cryst. Growth 2009, 311, 1296-1301. [CrossRef]

25. Lee, W.C.; Hu, C. Modeling CMOS tunneling currents through ultrathin gate oxide due to conduction- and valence-band electron and hole tunneling. IEEE Trans. Electron Devices 2001, 48, 1366-1373.

26. Yu, S.; Guan, X.; Wong, H.-S.P. Conduction mechanism of TiN/ $\mathrm{HfO}_{x} / \mathrm{Pt}$ resistive switching memory: A trap-assisted-tunneling model. Appl. Phys. Lett. 2011, 99. [CrossRef]

27. Entner, R.; Gehring, A.; Kosina, H.; Grasser, T.; Selberherr, S. Impact of multi-trap assisted tunneling on gate leakage of CMOS memory devices. NSTI Nanotech 2005, 3, 45-48. 
28. Vandelli, L.; Padovani, A.; Larcher, L.; Southwick, R.G.; Knowlton, W.B.; Bersuker, G. A Physical model of the temperature dependence of the current through $\mathrm{SiO}_{2} / \mathrm{HfO}_{2}$ stacks. IEEE Trans. Electron Devices 2011, 58, 2878-2887. [CrossRef]

29. Gehring, A.; Selberherr, S. Modeling of Tunneling Current and Gate Dielectric Reliability for Nonvolatile Memory Devices. IEEE Trans. Electron Devices 2004, 4, 306-319. [CrossRef]

30. Coenen, T.; Van de Groep, J.; Polman, A. Resonant modes of single silicon nanocavities excited by electron irradiation. ACS Nano 2013, 7, 1689-1698. [CrossRef] [PubMed]

31. Spinelli, P.; Macco, B.; Verschuuren, M.A.; Kessels, W.M.M.; Polman, A. $\mathrm{Al}_{2} \mathrm{O}_{3} / \mathrm{TiO}_{2}$ nano-pattern antireflection coating with ultralow surface recombination. Appl. Phys. Lett. 2013, 102. [CrossRef]

32. Brongersma, M.L.; Cui, Y.; Fan, S. Light management for photovoltaics using high-index nanostructures. Nat. Mater. 2014, 13, 451-460. [CrossRef] [PubMed]

(C) 2016 by the authors; licensee MDPI, Basel, Switzerland. This article is an open access article distributed under the terms and conditions of the Creative Commons Attribution (CC-BY) license (http://creativecommons.org/licenses/by/4.0/). 